\title{
ERBB2 Gene Product
}

National Cancer Institute

\section{Source}

National Cancer Institute. ERBB2 Gene Product. NCI Thesaurus. Code C45842.

A protein encoded by the ERBB2 gene. 